\title{
Chronological Restoration of Fort Frontenac in 3D for
} Heritage Visualization

\author{
Mitsuyoshi Yabe ${ }^{1}$, Elizabeth Goins ${ }^{2}$, Chris Jackson ${ }^{1}$, David Halbstein ${ }^{1}$, Shaun Foster ${ }^{1}$ and Sue Bazely ${ }^{3}$ \\ 1. Department of Visual Communication Design, Rochester Institute of Technology, Rochester 10605, New York, USA \\ 2. Department of Cultural Materials Science and Fine Arts, Rochester Institute of Technology, Rochester 10605, New York, USA \\ 3. Cataraqui Archaeological Research Foundation, Kingston K7L 1E1, Ontario, Canada
}

\begin{abstract}
This paper is composed of three elements: 3D modeling, web design and heritage visualization on the basis of the chronological restoration of Fort Frontenac in 1673, 1675, 1680, 1685 and 1688, changing from narrow and plain to broad, grand features. The aim is to use computer graphic design to inform and create an interest in historical visualization by rebuilding Fort Frontenac using 3D modeling and interactive design. The final model can be integrated into an interactive website to learn more about the fort's historic importance. It is apparent that using computer graphics can save time and money when it comes to historical visualization. Visitors do not have to travel to the actual archaeological buildings and can simply use the web in their own homes to learn about this information virtually. In order to create a sophisticated restoration of archaeological buildings, meticulously assessing historical records will draw viewers into the visualizations, such as the historical world of Fort Frontenac. As a result, the completed restoration allows the viewers to effectively understand the fort's social system, habits and historical events.
\end{abstract}

Key words: Heritage visualization, 3D computer graphics, interactive virtual design, web design, effective usage of learning.

\section{Introduction}

Fort Frontenac was an important military fortress and fur trading post that was built in Kingston, Ontario, Canada in 1673. The fort was renovated four times, initially by replacing log palings with masonry walls and adding bastions while it was embroiled in occasional outbreaks of fighting between the Iroquois and the British. When the reconstruction of the fort was completed, it became an impressive. However, the newly reconstructed fort was destroyed in 1689 but was then later reconstructed in 1695 to strengthen military activity and accommodation. Over the course of 50 years, fur trade gradually became more unprofitable, and the fort was relinquished to British forces who devastated it during the Seven Years' War in 1758. The fort was never rebuilt and was abandoned, because the fortification was no longer needed. New buildings and streets were then erected above its ruins for more than a

Corresponding author: Mitsuyoshi Yabe, M.Sc., research field: virtual archaeology. E-mail: mxy3663@rit.edu. hundred years. In 1983, archaeological research finally successfully excavated only a small portion of the fort, the northwest bastion (Fig. 1). The fort was designated as a Canadian National Historic Site, and a part of the northwest bastion was reconstructed in 1984 [1, 2].

This paper aimed at virtually reconstructing all the buildings to look like the provenance of the buildings. The field that embraces this process is called "heritage visualization", which is derived from a combination of the use of conventional archaeology and cutting-edge 3D computer graphics design. It represents a great opportunity to rebuild Fort Frontenac using this technique because many forts have been renovated in this manner to show historical reenactment sites.

This research aims at virtually restoring an archaeological building, Fort Frontenac, which in turn will draw viewers into the historical world of Fort Frontenac. This is a difficult task because there is limited information and only a small amount of archaeological remains from the original fort. While the original maps and plans of Fort Frontenac are 


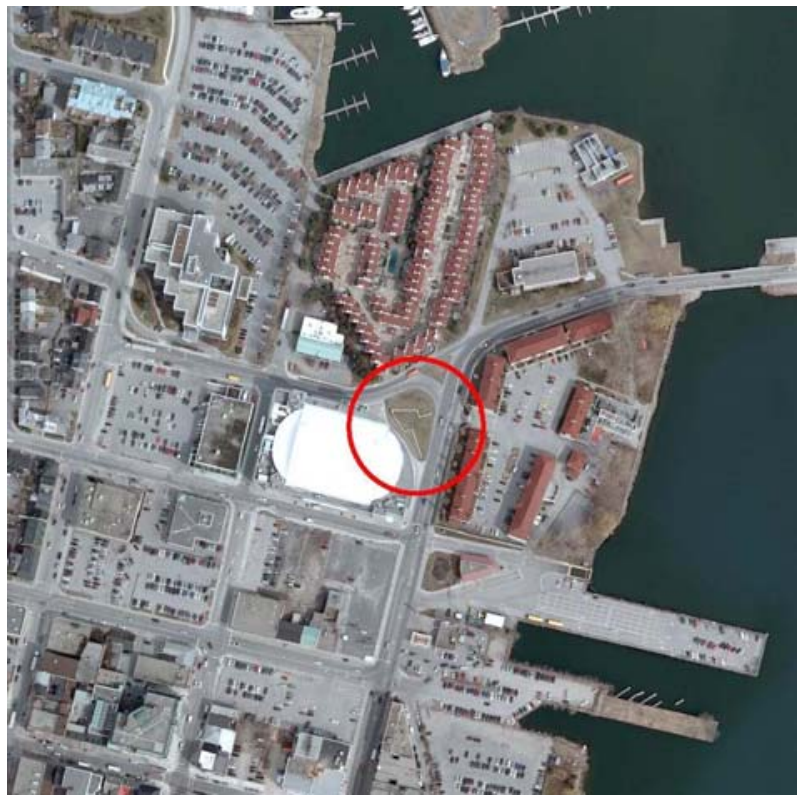

Fig. 1 Aerial imagery of surroundings around the remnants of Fort Frontenac ${ }^{\odot}$ (the City of Kingston Copyright 2011).

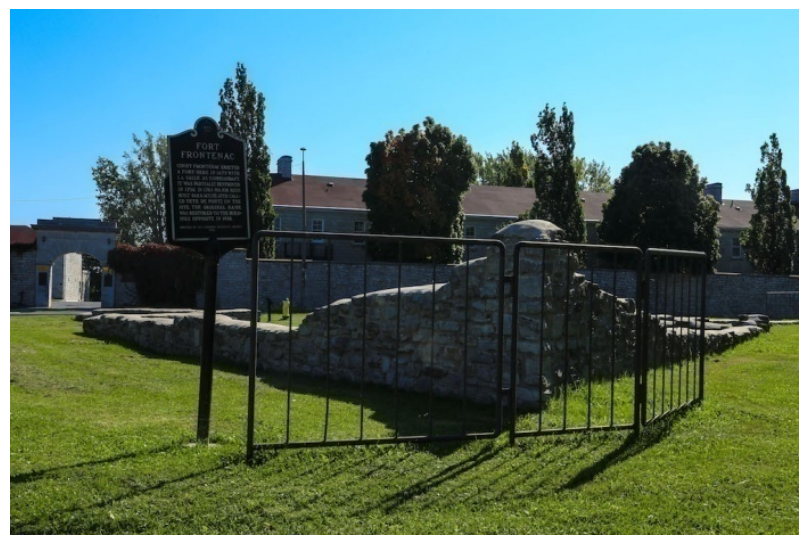

Fig. 2 The remnants of Fort Frontenac.

incomplete, a fertile imagination and computer graphics design skills are essential if the field is to help correct false assumptions regarding historical viewpoints. For example, what were the colors of the buildings? Color may be involved with an overly subjective viewpoint. What were its social system, habits and historical events of that time? Application of this field will also allow viewers to effectively understand the fort's social system and historical events. The target audience is those who are interested in history and archaeology. For those who are not able to visit Fort Frontenac because it is too far away from their residence, this thesis is designed to expand their knowledge while saving money and time. Historical Visualization is a vital field by means of internet access to view not only the fort but also many other forts, as well as other historic buildings and their architectural features, such as castles, all over the world. The important method of these processes is to disseminate this unique idea used for educational and economic purposes.

\section{Methology}

\subsection{Design Approach}

First, in order to approach a true picture of Fort Frontenac and its surroundings as they existed in the past, meticulous research was required via historical maps, plans and architectural styles of the fort at that time using the Internet and libraries. However, a physical visit and an archeologist's opinion are more advantageous to developing exceptional research. The dates that this researcher visited Kingston, Canada were on December 3, 2013 and on September 26, 2014 (Fig. 2) in order to photograph and glean information about the target fort. Furthermore, a consultation with a local archaeologist, Mrs. Susan Bazely [3], was well worth the opportunity to share her knowledge, experience in archaeological research and insights for research development. A good guide for the 3D modeling using Maya Software was to set up to scan drawings and blueprints.

After the design research was completed, the following practical softwares were essential to building models: Adobe Photoshop, CrazyBumps and Autodesk Maya. The exterior of the fortress was constructed in five steps, including the following years: 1673, 1675, 1680, 1685 and 1688. The used 3D modeling techniques included polygon modeling, shading and lighting. The textures of the buildings were shaded, and the background of the buildings and its surrounding environment were added by lighting adjustment. The completed models were rendered to produce video clips and interactive animations through camera movement, which were set in motion as a 3D camera 
was placed to create a bird's eye-view and a 360-degree view from the fort.

After the modeling was complete, interactive sceneries in Adobe Flash were devised to provide an effective way to implement visual communication and learning through the use of a mouse. Interactivity was integrated into the 3D models of the fort with unseen clickable buttons in order to allow the viewer to learn more about the fort's structure and historical importance. The video clips and interactive sceneries were integrated into the website in order to inform the user of the fort's social systems and historical events.

\subsection{Modeling Buildings in Maya}

\subsubsection{Constructing Buildings and Environment}

Maya 2014 is a professional tool that has the means of modeling physical objects and rendering sequences to create animations. By complying with the notes regarding the archaeological and historical consequences produced from research, photos of the forts, online documentation and historical plans and print documentation provided by the City of Kingston and Mrs. Bazely's evidence ${ }^{1}$, the careful operation was performed in Maya in order to fashion the length, height and size of each building, including the log palisades, curtain walls and moats.

In addition, CrazyBumps is a convenient software program for shading textural materials, where photos were simultaneously turned into displacement and normal maps. The software is the most effective, simplest and easiest way of creating these types of maps, since the software is beneficial to the enhancement of aesthetics and contrast. Four, six or eight images became two or four of each image by means of flipping the images vertically and horizontally and then stitching the original whole images together with much repetition in Photoshop. The images were offset, and the clone tool was used to make seamless repeating patterns. The more images

${ }^{1}$ Bazely, S. M., email message to Mitsuyoshi Yabe, February 26, 2014. that were put onto the one large image in Photoshop, the more realistic the textures of the buildings were when the images were transformed to displacement and normal maps adjusted by CrazyBumps according to intensity sharpen, detail, shade and highlight, which were then imported into Maya. Finally, the normal maps were placed along with the displacement maps onto a Blinn bump map for particular buildings. Most texture images were provided by a website referenced as Cgtextures, which has a wide amount of abundant textural resources that range from ancient to modern.

The log textures were from Cgtexture, and the limestone textures were from the remnants of Fort Frontenac. The six similar repeated images were stitched together using offset in Photoshop in order to respectively adjust the surfaces of each pole with the UV texture editor, protruding a $2 \mathrm{D}$ texture image to the 3D model's surface in Maya. For the roofs and wooden walls of the two storehouses, the textures were also found in Cgtexture and were created by the same means of Photoshop and CrazyBumps with the results

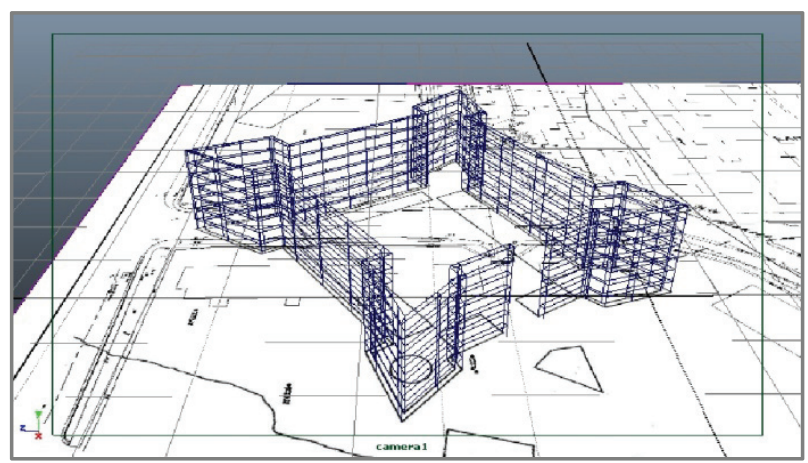

Fig. 3 The prototypical, wireframe model of the 1688 fortress.

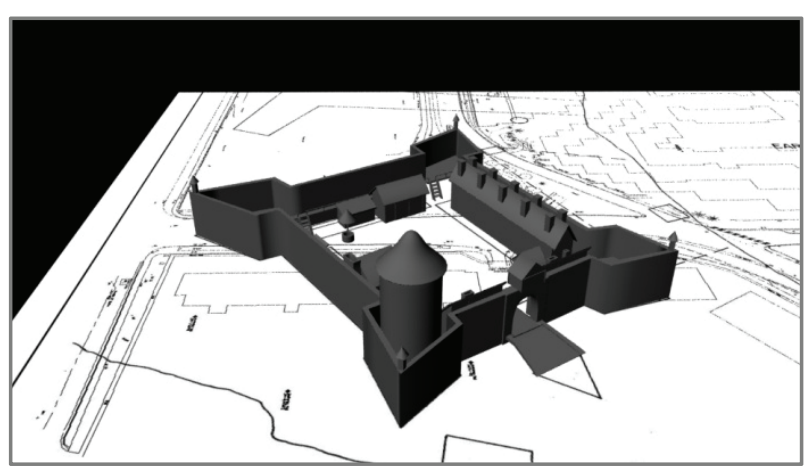

Fig. 4 The foundation model of the 1688 fortress with only solid. 


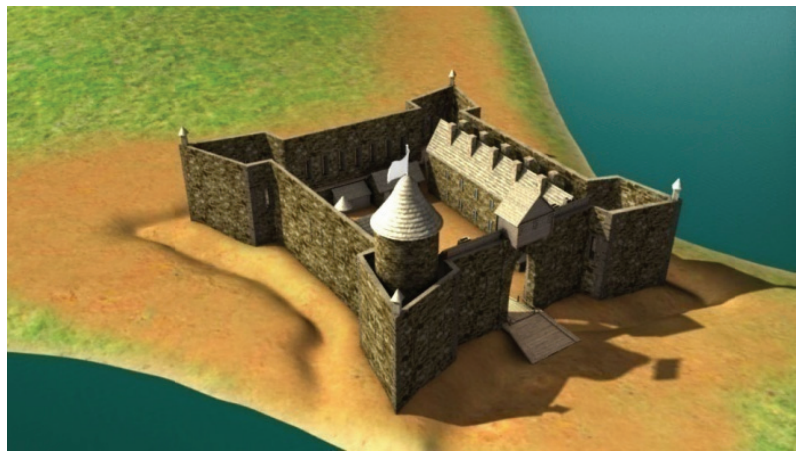

Fig. 5 The completed model of the $\mathbf{1 6 8 8}$ fortress with all the features.

placed onto bump maps using Maya. Textures were then put on each building by following these methods (Figs. 3-5).

Geographic landscapes were created in Maya by means of tracing curves over the outline of the plans for 1685 [4], which were provided by the City of Kingston. The outline became a planar surface and that surface was further converted into a polygon surface with numerous quarter geometries. The geometric maps shot by the UV snapshot process were included in the UV texture editor in Maya and were imported into Photoshop to create color geographic topography. A displacement map and a normal map were created in CrazyBumps and were then imported back into Maya to be placed onto a bump map for the landscapes. Moreover, the sea was created by means of using an Ocean Shader and Ocean, and minor corrections were required until the color was very similar to the color of the sea around Kingston that was dully emerald or bluish in color.

Three lights were also set up: key light, fill light and back light. The key light was like sunlight set as a directional light, turned towards the north, and its color was slightly bright yellowish. The fill light was a secondary light set as a spot light facing southwestward, and its color was slightly bluish. The back light was the third light set as an additional spot light in a southern direction, and its color was dimly warm orange. Originally, the fort's gate was turned northeast so that the entrance was in shadow. The three lights were crucial materials used to heighten an aesthetic sense of natural imagery. In order to create a dynamic moving sky, the sky image was distorted using polar coordinators in Photoshop and the hemisphere modeling was mapped with this image onto the UV texture editor under spherical mapping to eliminate seams in the top sky. It was designed for use as a camera application to further an appreciation of the area's natural aesthetics. Lastly, in order to make shadows look realistic, AO (ambient occlusion) can be used to help soften and deepen shadows and to refine a clearly visible separation between objects in a totally white scene. This technique can create a more realistic AO rendering (Fig. 6).

2.2.2 Rendering Sequences to Create Videos and Interactive Design

Regarding the camera animation, rendering PNG (portable network graphics) sequences featured an overview of the forts for a series of all construction dates and inside views of the forts for 1675, 1680, 1685 and 1688 , as well as providing ambient occlusion renderings for all of those scenes in video clips. The 1673 version was not included because the inside view was too narrow to create a video. A "Two Node" camera was set as the camera body and aim constraint. Different circular curves were created to become a motion path attached to each camera in order to make the cameras move very smoothly. Nine hundred frames were required for an overview of the exterior of the 1688 fort and ambient occlusion renderings for the fort in sequence. It took an average of $6 \sim 9 \mathrm{~h}$ to get this smooth for the videos.

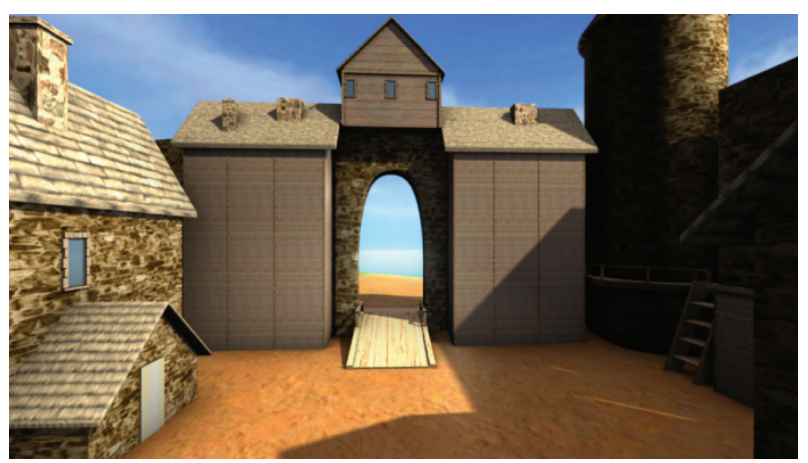

Fig. 6 The restoration of the entrance of Fort Frontenac in 3D computer graphics. 
Both of the completed sequences were imported into Adobe After Effects software and then placed as AO sequences under the "multiple" color sequences setting in order to be semitransparent, making the sceneries appear more realistic and then rendered for videos. The preferable time length for the videos was $24 \mathrm{~s}$ for an overview of the exterior. These setups were needed to make viewers visually comfortable according to the motion and timing.

Two videos were set as a chronological series of the two kinds of entire exteriors of the forts. The images for each were simply taken from Maya, which was an easy way to ensure that each image was ordered chronologically, and the corresponding chronological date texts were aesthetically put on each of the images in After Effects. For the aspect of interactive design, only 36 frames were required to render an overview of the exterior and interior of the forts, including ambient occlusion renderings for both locations. It took $30 \mathrm{~min}$ to set all the frames and install the historical sequences respectively for 1673, 1675, 1680, 1685 and 1688 .

\subsection{Creating Interactive Imagery in Flash}

Flash is reliable software designed to play a major role in interactivity. An SWF (small web format) generated from Flash was designed for the interactive application of this project and was equipped to become integrated with the website. From a technical viewpoint, the interactive animation was set up to play at a rate of only 36 frames. The coding was typed and fixed on the action scripts in order to fit the interactive scenery (Appendix B), and the names and descriptions of each building were placed in panels. The descriptions were integrated from the research result derived from trustworthy online and print documentation. These panels were placed around each building using transparent black color with high opacity, and Palatino Linotype was used as the font type presented in white text on the basis of its visual effect. Once the SWFs were published, the interactive system enabled users to hover over a certain building with a mouse where the panels, including its name and description, popped out (Fig. 7). This idea can be a useful educational tool to let users learn about the fort's historical importance and to acquire new knowledge, as well as assisting in the development of educational and study materials.

\subsection{Designing the Website}

Wix, as a website hosting and design tool, provided indispensable web assistance, which is helpful to a beginner in designing attractive websites without coding within a short time frame. The Wix website was able to convey information more effectively within a limited time than other types of multimedia. In terms of layout design, the color of the top bar was a slight crimson, and the main background was slightly yellowish beige or grey with high opacity under the old map. The reason for the color choices was that the outline and background of the old fort's map plan had colors in common with the roof and wall of the National Defence College that were built on the front of the fort's remnants. The site reanimates time reenactments of French settlements in Canada (Fig. 8).

\subsection{Critical Analysis and Troubleshooting}

The initial plan was to create three kinds of videos: an outside overview of the forts, an inside overview of the forts and a close-up of the gate for each of the years: 1673, 1675 and 1688. Nine hundred frames were essentially required to produce a 36-s video for the outside overview, 600 frames to produce a 24-s video for the inside overview and 360 frames to produce a

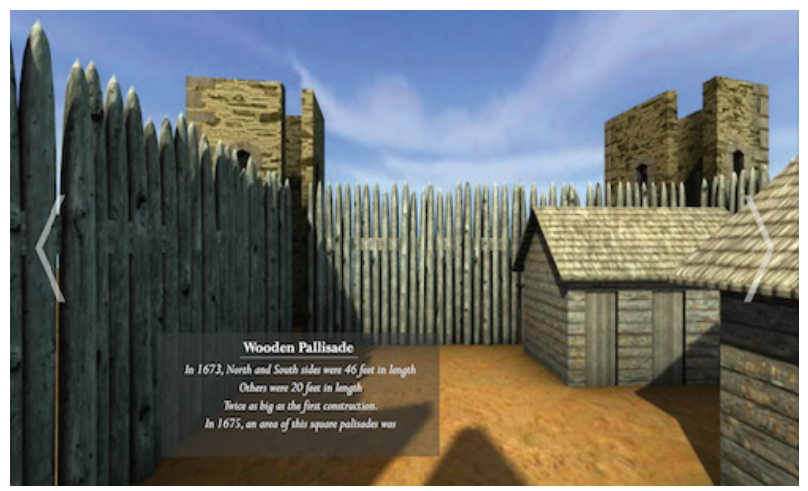

Fig. 7 The interactive scenery of the 1675 interior fortress. 


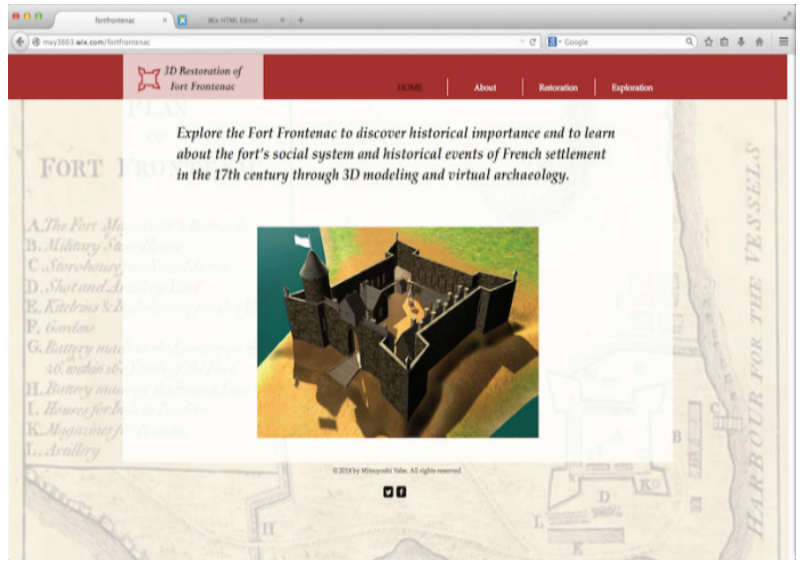

Fig. 8 The website of the 3D restoration of Fort Frontenac.

12-s video for the close-up of the gate. Rendering 900 frames greatly impacted the researcher's lifestyle on a daily basis, in that it took one day to complete one video. To create the full set of nine videos required a week. On the other hand, to create interactive sceneries for the outside and inside of the forts in Flash CC took only $30 \mathrm{~m}$ to render all 24 frames necessary to build a 360-degree interaction in Flash. At that rate, more than 10 interactions could be created on a day.

However, designing a related website was influenced by the video file formats and interactive sceneries for each page. User-centered design determined the best method to incorporate the videos. Consequently, most videos were removed due to their memory-intensive usage and the time management required. Only the videos for the completed exterior fort in 1688 were uploaded for the webpage. The completed website featured nine interactive sceneries: the exteriors for $1673,1675,1680,1685$ and 1688 , as well as their interiors respectively, except for 1673 . The appearance of the website was innovative and comfortable for users and enhanced their knowledge in an effective way, while in comparison, watching videos was not innovative and banal. To sum up, the use of this design could assert that interactive applications are attractive to users and usefully economize the time spent creating them, but featuring videos is relatively conventional and expends considerable effort and time.

\section{Chronological Restoration}

\subsection{The 1673 Fort Restoration}

The original fortress looked very crude because the construction was completed in less than a week due to Indian attacks and the need for enhancement to the security of the fort as a trading post. The constructed buildings included the following: a well, two storehouses for provisions and ammunitions storage, $\log$ palisades whose north and south sides were $46 \mathrm{ft}$ and whose other sides were $20 \mathrm{ft}$ in length [5]. For the restoration of the wooden palisades, as a sequel to researching their detailed textures among common trees in Kingston, wood was taken from a kind of sugar maple, bur oak, beech or eastern cedar (Fig. 9).

\subsection{The 1675 Fort Restoration}

The second fortress was rebuilt two years later because it was needed as an evident sign of the French presence on Lake Ontario. In this renovation, the log palisades had the addition of four limestone square bastions in an area that was 800 yards in circumference [5]. The masonry of the bastions was originally cut from the bedrock and covered below the soil where the fort was erected. The surfaces appeared to be yellowish, rough and blunt ${ }^{2}$ (Fig. 10).

\subsection{The 1680 Fort Restoration}

To serve the needs of the garrison, traders and native people, a complex of buildings had developed inside

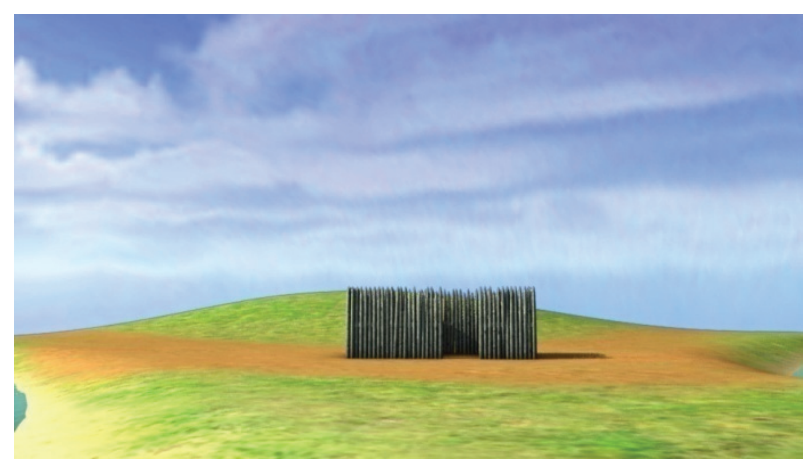

Fig. 9 The front of the 1673 fortress. 


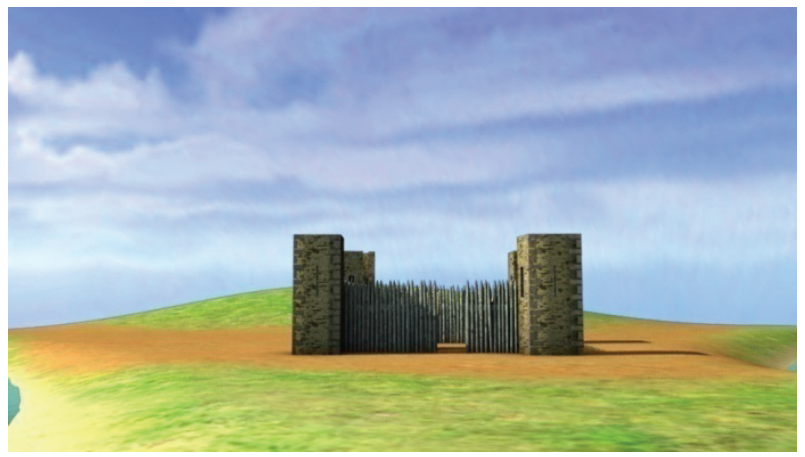

Fig. 10 The front of the 1675 fortress.

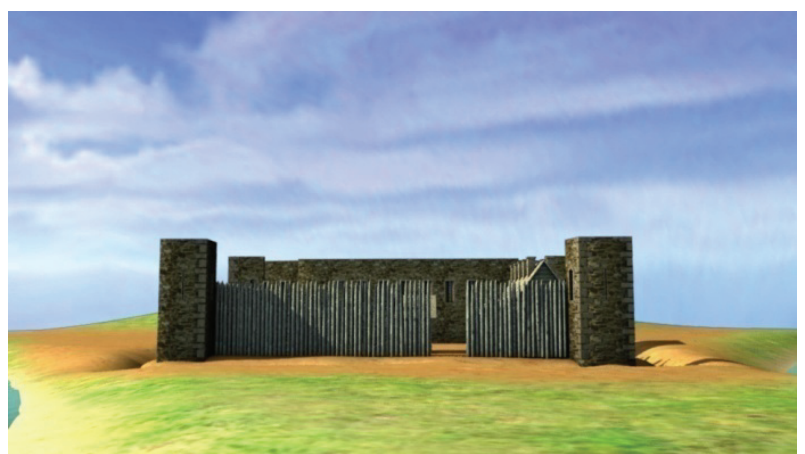

Fig. 11 The front of the 1680 fortress.

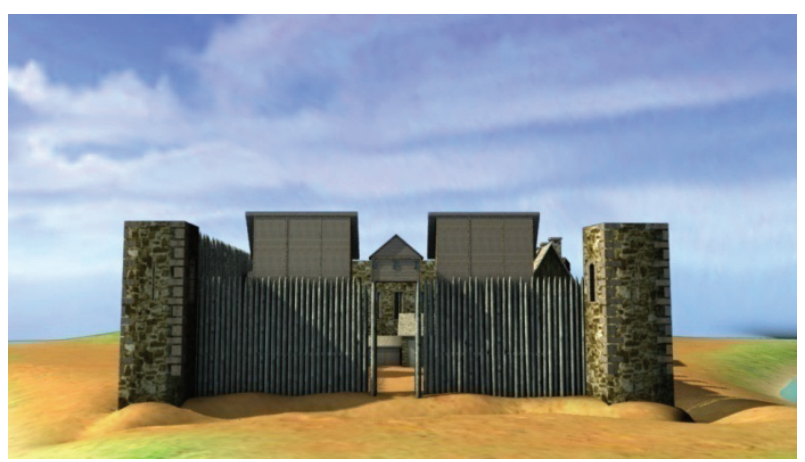

Fig. 12 The front of the 1685 fortress.

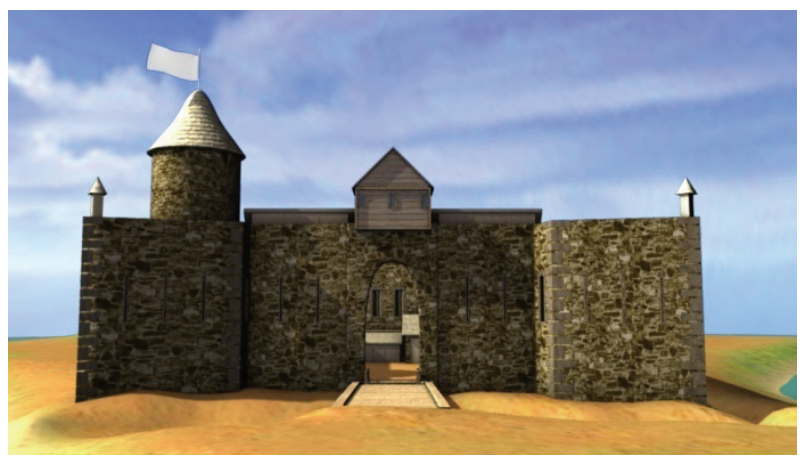

Fig. 13 The front of the 1688 fortress.

the fort. The constructed buildings included the following: a 100-ft-long quarter, a blacksmith shop, a guardhouse, a cow house, a well, wooden platforms and scaffolds and log palisades on the north, east and south sides, as well as masonry curtain walls on the west side, with the addition of four limestone square bastions. Around the fort were 15-ft-wide ditches [5]. The masonry curtain walls included many casements and loopholes [6] (Fig. 11).

\subsection{The 1685 Fort Restoration}

About 2,000 men built the masonry curtain walls and the bastions [6]. The fort was enlarged in a square alongside each of four bastions, which measured approximately $96 \mathrm{ft}$ from curtain wall to curtain wall. The south side had a combination of a 4-ft-high masonry foundation wall and log palisade that stood on the foundation wall. The inside included a masonry quarters or barracks, a guardhouse, a forge, mills, a powder magazine, a bakery, trade house, a well, a sentry-box and moats that were $15 \mathrm{ft}$ deep [5]. An architect inspected the fort and reported that the height of the walls was still too low [6] (Fig. 12).

\subsection{The 1688 Fort Restoration}

The additionally constructed buildings included the following: a large tower and four small towers, wooden platforms and scaffolds, a wooden bridge, a masonry gate and full limestone curtain walls with many casements and loopholes [5]. Most of buildings were completely transformed from wooden surfaces to limestone surfaces. However, some buildings still remained with wooden textures. Both textures were replaced because the fort had to be strongly reinforced due to the improvement of the military services and the interior exploration. Although the features were fine looking, there was no reassurance of safety. Only one year later, the fort was destroyed by Indian attacks [6] (Fig. 13).

\subsection{Output of the Fort Restoration}

The main output of this project can capture the important features of the fort restoration in 
chronological order. As these figures show, the width of the walls was obviously broader when it was being renovated as time passed, whereas its height remained the same. Additionally, Appendixes A and B indicate the size and materials of the walls and the interior buildings. This information resulted from a clear relationship between the height and weight of the fortress wall in the context to the fact that it was constructed for the number of garrisons required. In 1673 , there were 400 men, including soldiers, traders and French inhabitants, and by 1685 , there were 2,000 men [5]. The number of garrisons was not clear, but garrisons increased in proportion to a total of all the men participating in the fort. The number of buildings inside the fort was increasing, and building materials were becoming stronger and more highly qualified for the task.

Masonry walls were gradually added to improve the security of the fort against occasional attacks by the Iroquois. However, although the fort was not fully destroyed by these attacks, the settlement was totally spoiled due to Iroquois attack and the prevalence of scurvy among its settlers. The number presented at the garrison was quickly reduced to only 13 defenders, so as a result, the French destroyed the newly restored fort due to a lack of military defense and supplies so in that case all the walls did not get any taller from that time forward [6].

\section{Conclusions}

Proving this collaborative evidence needed videos and interactive sceneries of the front view and the 360-degree view of exterior and interior of the fortress. Following the videos and interactive sceneries of the chronological restoration of Fort Frontenac in 1673, $1675,1680,1685$ and 1688 , the width of the walls gradually widened, whereas their height did not change. The number of the garrisons living inside the fort also affected the direct relationship between the width and the height of its walls. To produce the videos and interactive sceneries, modeling the buildings and the related environment created a lot of challenges and many difficulties because there was very little information available about the 17th-century Fort Frontenac. Further research and information were needed to clarify that Fort Frontenac compared with other forts that were relatively similar to the target fort, according to their various sizes, such as the height, length and width of buildings, as well as the textures of the buildings and the environment surrounding them. To make the visual motion smooth and slow, 900 frames in the rendering sequences were required to create the video clips. Needless to say, the average rendering time was $9 \mathrm{~h}$, and occasionally several defections from the rendering occurred, so supervision was important to the rendering several times each hour.

By changing the consumer's understanding to an archaeological viewpoint, the field continues to evolve step-by-step. The 3D techniques and web design gradually support this evolution, even though the technology is still developing in areas, such as comfort and convenience for modeling, importing colors and sounds, lighting, shading, setting items into motion in $3 \mathrm{D}$, visually communicating a $3 \mathrm{D}$ screen, and interactively using a mouse on a website. The project can state facts backing up historical sites that have been abolished, are in bad condition or are in repair, which can then be resuscitated and examined through the use of the latest technology, such as videos and interactive sceneries and those in this research that demonstrate and prove the different sizes of the fort restoration as they occurred in chronological order.

\section{Acknowledgments}

The authors would like to thank Dr. Elizabeth Goins, Mr. Chris Jackson, Mr. David Halbstein, Mr. Shaun Foster and Mrs. Susan Bazely for giving useful advice on this research work.

\section{References}

[1] Canada's Historic Place. 1984. "Fort Frontenac National Historic Site of Canada." Canada's Historic Place. Accessed September 10, 2013. http://www.historicplaces. 
ca/en/rep-reg/place-lieu.aspx?id=12130.

[2] Cataraqui Archaeological Research foundation. n.d. "Fort Frontenc.” Cataraqui Archaeological Research Foundation. Accessed September 10, 2013. http://www.carf.info/kings ton-past/fort-frontenac.

[3] Bazely, S. M., Fernandez, J., and Sheldon, H. 2007. Archaeological Assessment Place D'Armes Re-Alignment Kingston, Ontario. Kingston: Cataraqui Archaeological Research Foundation.

[4] Engineering Division Planning and Development
Services. 2006. Fort Frontenac Based on a 1685 Map. Map Scale 1:1000. Kingston: Engineering Division Planning and Development Services in City of Kingston.

[5] Stewart, B. W. 1982. The Kingston Harbourfront Archaeological Project Phase II, Fort Frontenac: Results of the 1982 Test Excavations. Kingston: Cataraqui Archaeological Research Foundation.

[6] Preston, R. A. 1958. Royal Fort Frontenac. Toronto: The Champlain Society. 
Appendix A: The table of architectural and chronological data of the fort construction of the exterior and the interior.

\begin{tabular}{|c|c|c|c|c|c|c|c|c|c|c|}
\hline Year & South wall & West wall & North wall & East wall & Height & Length & Width & Overview & Inside & Ref./Page\# \\
\hline 1673 & Wood & Wood & Wood & Wood & - & $\begin{array}{l}\text { One, } 46 \mathrm{ft} \\
(14 \mathrm{~m}) \text {; the } \\
\text { other, } 20 \mathrm{ft} \\
(6.1 \mathrm{~m})\end{array}$ & - & Wooden palisaded post & $\begin{array}{l}\text { Two small storehouses for } \\
\text { provisions and ammunition }\end{array}$ & Stewart [5]/p.5 \\
\hline 1675 & - & - & - & - & $\begin{array}{l}\text { A rampart } \\
\text { with four } \\
\text { bastions, } 12 \\
\mathrm{ft}(3.66 \mathrm{~m}) \\
\text { in height }\end{array}$ & 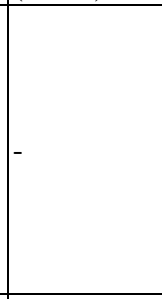 & $\begin{array}{l}\text { A rampart } \\
\text { with four } \\
\text { bastions, } 3 \\
\mathrm{ft}(0.91 \mathrm{~m}) \\
\text { in width }\end{array}$ & $\begin{array}{l}\text { A rampart with four } \\
\text { bastions faced with } \\
\text { masonry revetments, } 360 \\
\text { toise (approx. } 800 \text { yards = } \\
731.52 \text { m) in } \\
\text { circumference; } \\
\text { Twice as big as the first } \\
\text { construction }\end{array}$ & $\begin{array}{l}\text { The largest wooden house built of } \\
\text { squared logs, approx. } 100 \mathrm{ft} \text { in } \\
\text { length } \\
\text { A blacksmith shop, a guard house, } \\
\text { officers' quarters, a cow house, } \\
\text { and a well; } 15 \mathrm{ft}(4.57 \mathrm{~m}) \text { wide } \\
\text { defensive ditches around the fort } \\
\text { and a moat across the peninsula } \\
\end{array}$ & $\begin{array}{l}\text { Stewart [5]/p.6; } \\
\text { Preston } \\
{[6] / p .32}\end{array}$ \\
\hline 1680 & Wood & Masonry & Wood & Wood & - & - & - & - & - & Bazely [3]/p.8 \\
\hline 1682 & - & - & - & - & $\begin{array}{l}12 \mathrm{ft} \text { at the } \\
\text { base }\end{array}$ & - & $\begin{array}{l}3 \mathrm{ft} \text { at the } \\
\text { base }\end{array}$ & $\begin{array}{l}\text { Square in shape with four } \\
\text { bastions each of which } \\
\text { was } 15 \text { toise (approx. } 96 \mathrm{ft} \\
=87.78 \mathrm{~m} \text { ) from curtain } \\
\text { wall to curtain wall; } \\
\text { Two stone bastions } \\
\text { constructed of limestone }\end{array}$ & $\begin{array}{l}\text { Three quarters constructed of } \\
\text { limestone masonry with the } \\
\text { remaining side of the fort enclosed } \\
\text { with stakes; } \\
\text { The largest wooden house built of } \\
\text { squared logs, approx. } 100 \mathrm{ft} \text { ( } 30.5 \\
\text { m) in length. A blacksmith shop, a } \\
\text { guard house, officers' quarters, a } \\
\text { cow house and a well. }\end{array}$ & $\begin{array}{l}\text { Stewart } \\
\text { [5]/pp.6-7 }\end{array}$ \\
\hline 1685 & $\begin{array}{l}\text { Wood } \\
4 \mathrm{ft}(1.22 \mathrm{~m}) \\
\text { high foundation } \\
\text { wall associated } \\
\text { with the } \\
\text { southeast } \\
\text { bastion }\end{array}$ & $\begin{array}{l}\text { Two } \\
\text { associated } \\
\text { bastions } \\
\text { were } \\
\text { constructed } \\
\text { of masonry, } \\
12 \mathrm{ft} \text { height }\end{array}$ & Wood & Wood & $\begin{array}{l}12 \text {-ft-high- } \\
\text { masonry } \\
\text { wall, } \\
\text { including } \\
4 \text {-ft-high } \\
\text { foundation } \\
\text { and } \\
8 \text {-ft-high } \\
(2.44 \mathrm{~m}) \\
\text { palisade }\end{array}$ & |- & $\begin{array}{l}3 \mathrm{ft} \text { at the } \\
\text { base }\end{array}$ & $\begin{array}{l}\text { A combination of log } \\
\text { palisade and masonry } \\
\text { construction; } \\
\text { The existing bastions } \\
\text { associated with the } \\
\text { palisade wall which were } \\
\text { constructed of masonry; } \\
\text { Two bastions constructed } \\
\text { with a mortar made } \\
\text { without lime }\end{array}$ & $\begin{array}{l}\text { A barracks, a guard house, a } \\
\text { powder magazine, a mill, a bakery, } \\
\text { a sentry-box at the gate and a well }\end{array}$ & $\begin{array}{l}\text { Stewart } \\
\text { [5]/pp.7-8 } \\
\text { Fort Frontenac } \\
\text { or Catarakouy } \\
\text { La Salle's } \\
\text { Improvements } \\
\text { at Fort } \\
\text { Frontenac by } \\
\text { Cpl. Walter B. }\end{array}$ \\
\hline 1686 & - & - & Masonry & - & - & - & - & - & $\begin{array}{l}\text { The close association of the } \\
\text { palisade wall with the main } \\
\text { barracks }\end{array}$ & $\begin{array}{l}\text { Stewart } \\
{[5] / \text { p.10 }}\end{array}$ \\
\hline 1687 & - & - & - & - & - & - & - & - & $\begin{array}{l}\text { A tower erected for storing goods } \\
\text { and to serve as a lookout post }\end{array}$ & $\begin{array}{l}\text { Stewart } \\
{[5] / \text { p.10 }}\end{array}$ \\
\hline 1688 & Masonry & Masonry & Masonry & Masonry & & - & - & $\begin{array}{l}\text { All the walls constructed } \\
\text { of Masonry }\end{array}$ & - & Stewart[5]/p.10 \\
\hline
\end{tabular}


Appendix B: Codes in action scripts.

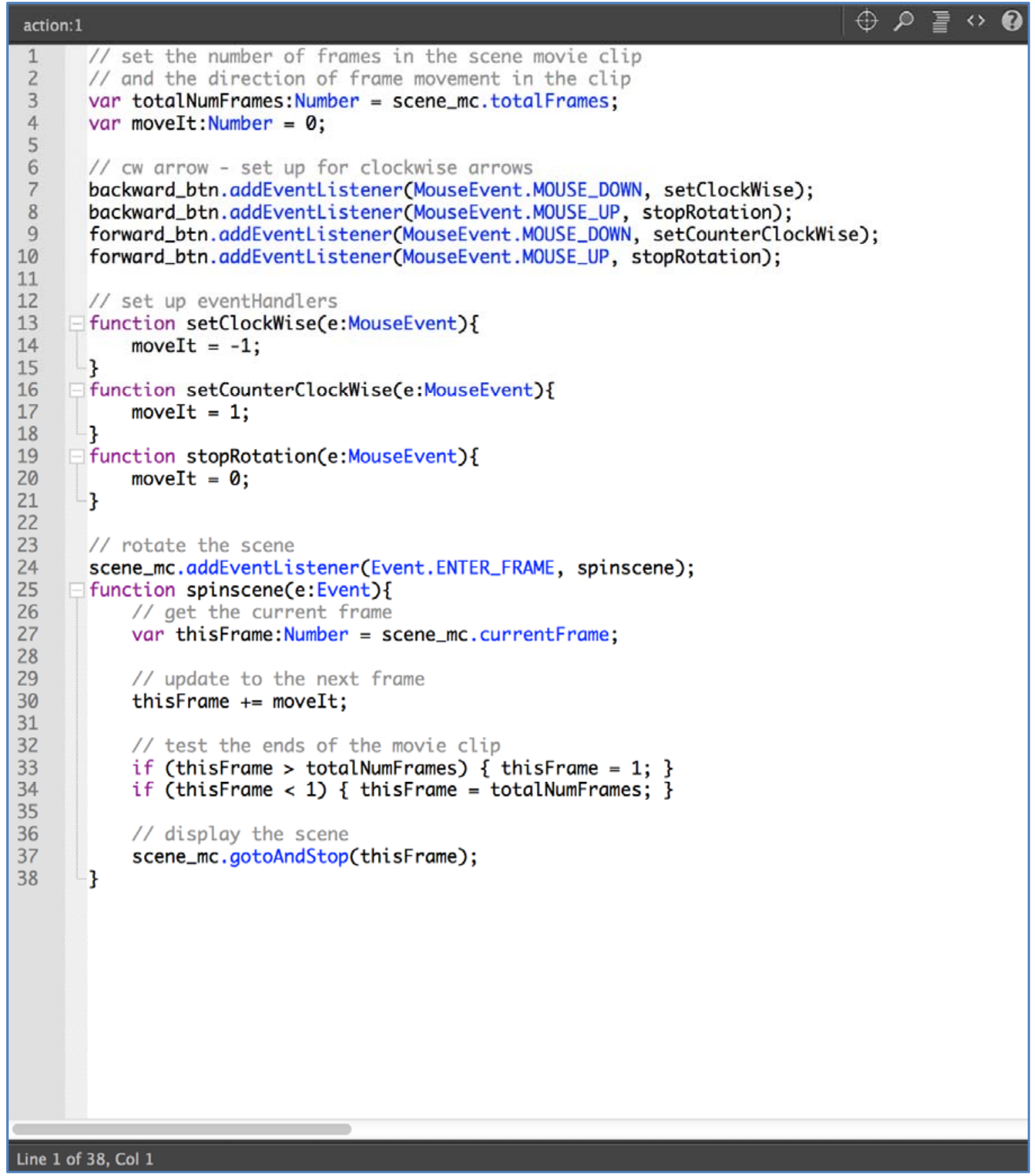

